\title{
LANDSCAPE AND HYDROMORPHOLOGICAL ASSESSMENT OF A MOUNTAIN RIVER VALLEY AFTER FLOOD STAGE
}

\author{
Maria Nawieśniak-Caesar ${ }^{1 凶}$, Józef Hernik ${ }^{1}$, Mateusz Strutyński² \\ ${ }^{1}$ Department of Land Management and Landscape Architecture, Faculty of Environmental Engineering and Land Surveying, \\ University of Agriculture in Krakow, ul. Balicka 253c, 30-149 Kraków \\ ${ }^{2}$ Department of Hydraulic Engineering and Geotechnics, Faculty of Environmental Engineering and Land Surveying, \\ University of Agriculture in Krakow, Al. Mickiewicza 24/28, 30-059 Kraków
}

\begin{abstract}
Aim of the study

This paper aims to present an integrated assessment of changes in a mountain river valley after a flood.

Material and methods

The assessment followed the LandScape \& HydroMorphological Assessment of River Valleys Method (LSHM Method). The method is intended for assessing and identifying valuable areas in river valleys and determining their development potential. The LSHM Method distinguishes three main groups of factors: hydromorphological (H), landscape (L), and integrated (I). All the factors are assessed using a 10-point scale.
\end{abstract}

\begin{abstract}
Results and conclusions
Landscape and hydromorphological assessment with the LSHM Method facilitates identifying transformations of both the river channel and valley together with the areas interrelated with the river, and assessment of integrated river valley landscape. The integrated approach can be applied in the planning of repairs when restoring a river valley after a flood.
\end{abstract}

Keywords: hydromorphological and landscape valorisation, LSHM Method, river valleys, flood

\section{INTRODUCTION}

When Poland became a member of the European Union in 2004, it ratified the Water Framework Directive (WFD) (Directive 2000/60/EC). The purpose of enforcing the Directive was to improve the quality of river ecosystems. Good status of surface waters is evidenced by biological and physicochemical quality elements, supported by hydromorphological elements. The implementation of the WFD (Directive 2000/60/ EC) saw the introduction of numerous methods for assessing hydromorphological quality of rivers (Belletti et al., 2015; Casado et al., 2015; Ioana-Toroimac et al.,
2015; Rinaldi et al., 2013), also in Poland. Methods used for hydromorphological assessment of watercourses in Poland come in two varieties (Lewandowski, 2012). The first one includes studies based on the British method, called the River Habitat Survey. It involves 500 metre-long sections with 10 cross-sections, 50 metres apart. In addition to the information collected at the cross-sections, features recorded between them and features of the surrounding valleys are also included in the study. Two parameters are obtained for each section: the HMS (Habitat Modification Score) and the HQA (Habitat Quality Assessment). The HMS facilitates a numeric representation of the range of anthropo-

凶e-mail:m.nawiesniak@ur.krakow.pl 
Nawieśniak-Caesar, M., Hernik, J., Strutyński, M. (2019). Landscape and hydromorphological assessment of a mountain river valley after flood stage. Acta Sci. Pol., Formatio Circumiectus, 18(1), 75-87. DOI: http://dx.doi.org/10.15576/ASP.FC/2019.18.1.75

genic changes in a river habitat. The HQA is related to the occurrence and diversity of natural elements of the watercourse and valley (Raven et al., 1998a; Raven et al., 1998b). The second group includes methods based on the assessment of rivers at cross-sections, which are located between 100 and 1000 metres apart. For each section, a 5-point scale is used to assess indicators (Lewandowski, 2012). Examples of such methods include: the Ilnicki-Lewandowski method (Ilnicki and Lewandowski, 1997), the Oglęcki-Pawłat method (Oglęcki and Pawłat, 2000), or the method for assessing hydromorphological quality of rivers (Wyżga et al., 2009; Wyżga et al., 2010; Wyżga et al., 2012). The method for assessing hydromorphological quality of rivers involves an evaluation of 10 categories of channel, bank, riparian zone, and floodplain features using a 5-point scale. Then, based on the average values of the parameters for each cross-section, the class of hydromorphological quality of the river is determined (Wyżga et al., 2009; Wyżga et al., 2010; Wyżga et al., 2012).

It is difficult to improve the hydromorphological status of a river. The process requires comprehensive corrective actions, or restitution. The intensity of hydromorphological processes in a channel depends mostly on flow dynamics and discharge. River channels change in particular during flood stage (Dufour et al., 2015; Vogt et al., 2004; Wyżga, 2001) when they may be shifted, braided, or deepened; meanders may be cut off to form oxbow lakes. Flood flows are key to the changes in the horizontal and vertical arrangement of the watercourse channel. They often result in changed river course, breaking away armoured bed, and mass bed load transport, which increases vertical erosion of the watercourse bed, and bed cuts down to the bedrock (Wyżga, 2001).

Increased human activity, particularly built development in catchment areas, which results in sealing the ground, and river regulation along the course, have resulted in increased intensity of hydrological processes and higher water level in the channel (Bartnik et al., 2009; Spänhoff et al., 2012; Allaire et al., 2015). It is important to differentiate between high water and flood discharges. The latter results in social and financial losses. Flood losses have so far been understood in terms of financial valuation, using the notion of flood risk, which combines threat and potential ramifications (Directive 2007/60/EC). However, the flood, in particular a low annual accident probability flood, changes the hydromorphology and the landscape of river valleys (Merz et al., 2009).

The European Landscape Convention (ELC) (Council of Europe 2000) was ratified in 2004. According to the Convention, the landscape, including river valley landscape, should be provided with a legal status and should be considered a basis for: quality of living, shaping of regional and local awareness, and the introduction of natural and cultural diversity (Council of Europe 2000). Landscapes should be provided with protection, management and planning - regardless whether it is a natural, cultural, urban, degraded, particularly beautiful, or a 'mundane' landscape (Stoeglehner and Schmid, 2007; Gulinck and Wagendorp, 2002). Today, the areas with valuable landscapes require proper and responsible management. The presence of valuable cultural landscapes should not limit, prevent, or hinder the economic use of the area (Hernik, 2008; Kühne et al., 2015). They cannot, however, be subject to uncontrolled appropriation. Until now, activities that affected the landscape, especially in Polish rural municipalities, were often uncoordinated (Sankowski et al., 2016; Hernik et al., 2013). Decisions regarding these measures were typically random, and they often reflected particular interests of various small groups. In order to correctly implement the assumptions of the ELC (Council of Europe 2000), the landscape must be identified and assessed.

ECOVAST is a method for assessment and identification of landscape that is used in Poland (Spiegler and Dower, 2006). It is based on a matrix, which serves to describe a number of features related to the landscape. Each feature is assigned a weight. The purpose of the ECOVAST method is to assess and identify areas of varied landscape values, in particular those that are the most precious, as well as the least valuable ones whose landscape quality needs improvement (Spiegler and Dower, 2006). Integrated landscape protection is a long-term process involving a variety of mutually supportive activities (Raszeja and Skóra, 2018).

Landscape research in Poland is not highly developed compared to other European landscape studies. Poland has very little experience in the management of landscapes at a local scale, and further studies should be conducted in this field (Solecka et al., 2018). Hydro- 
morphological research is better developed, though. In 2017, guidelines for the monitoring of hydromorphological elements and the assessment of the ecological status of running water were published (Szoszkiewicz et al., 2017). Nevertheless, hydromorphological and landscape elements are assessed separately (Nawieśniak et al., 2016, Nawieśniak, 2018). Landscape research traditionally focused on land, while it has much to offer, and even more to learn from, studies of aquatic systems, especially rivers and streams. Riverine systems are governed by water flows. Because of its density and viscosity, water is a much more effective agent in linking landscape elements, both in space and in scale, than the air in which terrestrial landscapes are immersed. Consequently, rivers and streams should be ideal settings for exploring landscape ecology (Wiens, 2002).

The goal of the paper is to assess the changes in a mountain river valley after a flood. The assessment involves hydromorphological changes in the river and the landscape of a small, mountainous river valley of unique landscape qualities after flood stage. The assessment followed the integrated LSHM method approach (Nawieśniak et al., 2016).

The studies presented in this paper were conducted in a selected, representative mountain catchment area. In such mountain catchments, the morphological changes after flood stage are most conspicuous, and they affect integrated river valley landscape. Application of the LSHM Method offers 'holistic', integrated knowledge of the river valley, showing what should be improved and where.

\section{MATERIALS AND METHODS}

The study of changes in a mountain river valley after a flood was conducted on the valley of the Krzyworzeka river, located in the Carpathian Mountains in southern Poland (see: Fig. 1). The Krzyworzeka is

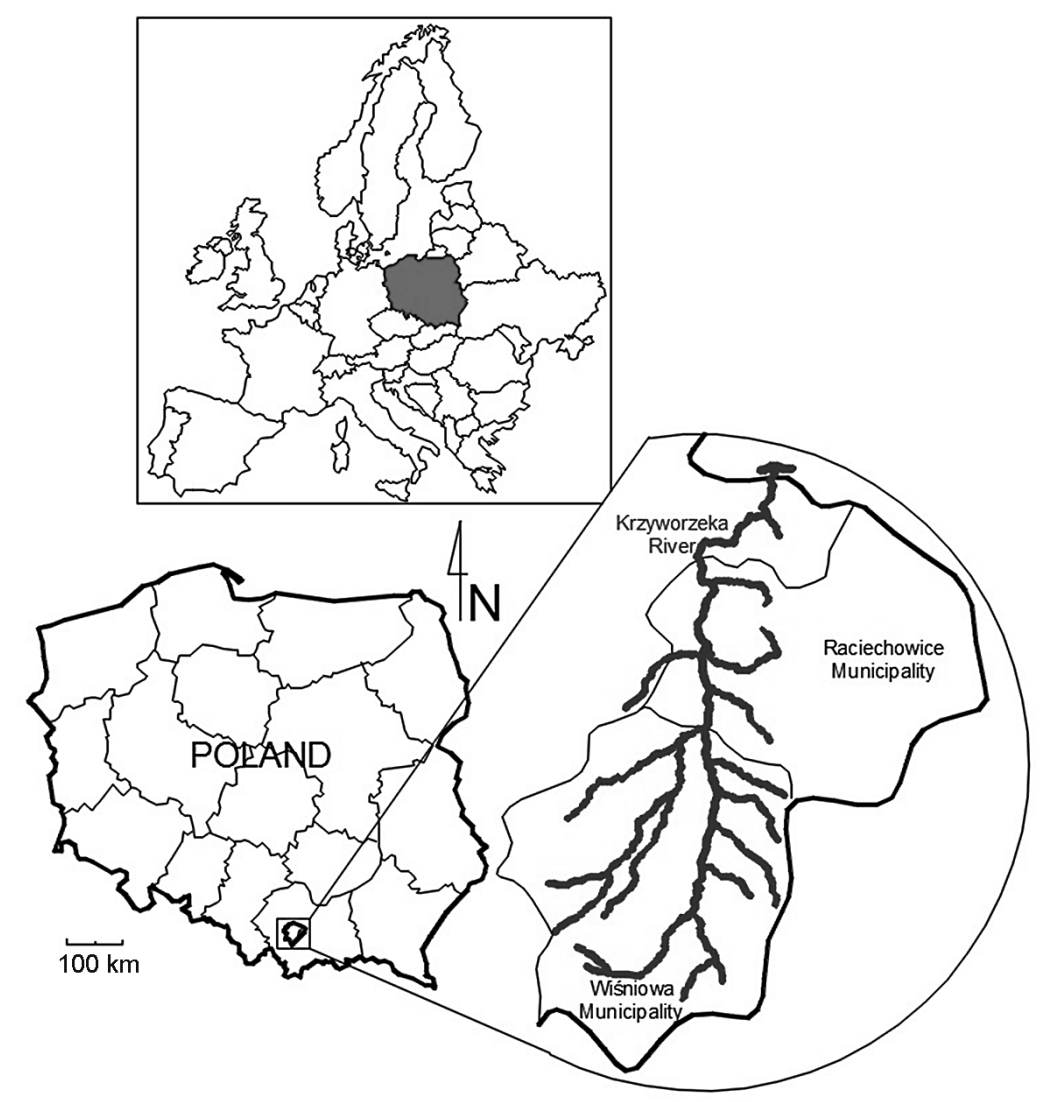

Fig. 1. Location of the Krzyworzeka Valley 
a right-bank tributary of the Raba river. Its total length is about $21.5 \mathrm{~km}$ (including the Kobielnik stream, which is believed to be the headwaters of the river). The surface area of the Krzyworzeka catchment at the confluence with the Raba river at $\mathrm{km} 54+125$, is 77.7 km² (Radecki-Pawlik, 1999). The Krzyworzeka is located in the territory of the Małopolska Region. The Krzyworzeka river flows through the Wiśniowa Municipality, Raciechowice Municipality (in the Myślenice District [second-tier administrative unit in Poland]) with its confluence in Gdów Municipality (in the Wieliczka District). It is joined by three tributaries in the Wiśnicz Plateau: the Sikornica, the Lipnik, and the Olszynka. The Krzyworzeka river is prone to spring and summer flooding. Owing to its location in the Carpathian Flysch, the armouring skeleton of the river is made up mainly of sandstone and mudstone with finer deposits. Suspended load is small, and it has no significant impact on channel morphology. Down to the average depth of $3.0 \mathrm{~m}$, the bed is made mainly of coarse sands and gravel from alluvial loams and few boulders. Below this level $(3.2 \mathrm{~m})$ there are schists, clays and fine sandstones (Radecki-Pawlik, 1999; 2002). In its upper course, the Krzyworzeka river flows through densely developed areas; while in its middle and lower courses, it flows through agricultural areas.

The study consisted of desk research, followed by field work. In order to conduct the field work correctly, the available and current documentation was studied first. The following were analysed: the archived topographic maps (Austrian map: Spezialkarte der Österreichisch-Ungarischen Monarchie dated 1907 and Tactical Map dated 1934 by the Military Institute of Geography); the current ortophoto of the studied area; and the spatial development plan for the Wiśniowa Municipality.

Field work involved the use of LandScape \& HydroMorphological Assessment of River Valleys Method (LSHM Method) (Nawieśniak et al., 2016), which was developed by merging and modifying two other methods: the ECOVAST landscape identification and assessment method, and the hydromorphological river quality assessment method. The method is intended for assessing and identifying valuable areas in river valleys and determining their development potential. The LSHM Method distinguishes three main groups of factors: hydromorphological $(\mathrm{H})$, landscape (L), and integrated (I) ones. All the factors are assessed using a 10-point scale and assigned to one of five classes $(0 ; 1-2 ; 3-5 ; 6-8 ; 9-10)$.

The first group of elements, the hydromorphological factors, pertains solely to the river channel. This group includes the following parameters: geometry of the watercourse $(\mathrm{H}-1)$, watercourse bed material $(\mathrm{H}-2)$, plant life in the channel (H-3), and erosion/ deposition $(\mathrm{H}-4)$. Table 1 shows extreme values for the assessed parameters according to the LSHM Method.

Parameters assessed in the second group - the landscape elements - include: land cover and topography (L-1), open landscape (L-2), settlement areas (L-3), and historic features/ structures (L-4). Extreme values for this group of elements as per the LSHM Method are shown in Table 2.

The elements in the third group are integrated elements (I), which could not be positively assigned to either of the previous groups. These parameters integrate hydromorphological and landscape elements: flow characteristics (I-1), anthropogenic elements/ modifications (I-2), land use and vegetation in areas adjacent to watercourse channel (I-3), as well as mobility and connection of the channel to floodplain and/ or adjacent open area (I-4). Table 3 contains extreme values for the parameters according to the LSHM Method.

The values assigned to individual elements (parameters) indicate the attractiveness (or the lack of attractiveness) of the studied area. River valley landscapes were divided into 3 groups according to the economic and tourist attractiveness in order to apply the LSHM Method. The first group (mean values of the assessed elements as per the LSHM Method vary from 7 to 10) includes a very attractive area with a complex network of pedestrian routes, pavements and economic and tourist facilities. The tourists visiting the area do not harm the environment. The channel of the watercourse can shift freely. It is a natural (unregulated) channel, which poses no flood threat to adjacent areas. The second group (mean values for the assessed elements as per the LSHM Method vary from 3 to 7) contains a moderately attractive area. This area has pedestrian routes and pavements, but no economic or tourist facilities, that would pose a threat to the environment. The channel of the watercourse is natural (unregulat- 
ed) but it cannot shift, which poses a flood threat to adjacent areas. The third group contains an unappealing area (mean values for the assessed elements as per the LSHM Method vary from 0 to 3 ). The area has no pedestrian routes and no economic or tourist facilities. The tourists (anglers) who visit the landscape area of this river valley damage the environment. The channel of the watercourse is regulated and it cannot shift, which poses a flood threat to adjacent areas. This division does not apply to river valley landscapes in national parks, natural landscape parks, or areas under special landscape protection.
The hydromorphological and landscape assessment according to the LSHM Method was conducted twice: in 2014 and 2015 in the Krzyworzeka valley, from $\mathrm{km} 6+157$ (Czasław) to $\mathrm{km} \mathrm{14+657} \mathrm{(Wiśnio-}$ wa). The studied area is the middle course of the river, which is also the most modified, owing to the housing developments, partially directly adjoining the channel. The selected sector exhibits significant hydromorphological diversity: substantial depressions in the riverbed and varied riffle-pool sequences. It was divided into 13 cross-sections along the axis of bridges across the river channel (see: Fig. 2).

Table 1. Extreme values of hydromorphological elements as per the LSHM Method

\begin{tabular}{|c|c|c|}
\hline \multirow{2}{*}{ Hydromorphological elements $(\mathrm{H})$} & \multicolumn{2}{|c|}{ Scale } \\
\hline & $10-9$ & 0 \\
\hline $\begin{array}{l}\text { Watercourse geometry (H-1) - assessed } \\
\text { value of change in the channel } \\
\text { section, change (or lack thereof) in the } \\
\text { longitudinal profile and cross-sections of } \\
\text { the watercourse }\end{array}$ & $\begin{array}{l}\text { up to } 5 \% \text { of the section of the } \\
\text { watercourse channel changed, no human } \\
\text { impact (or minimal interference) in the } \\
\text { course of the river channel, no change } \\
\text { in the longitudinal profile and cross } \\
\text { sections of the river, any changes are } \\
\text { slight, almost imperceptible }\end{array}$ & $\begin{array}{l}90 \text { to } 100 \% \text { of the section of the } \\
\text { watercourse channel changed, change } \\
\text { in the entire geometry and course of the } \\
\text { river channel (straightened), complete } \\
\text { change in the longitudinal profile and } \\
\text { cross-sections of the watercourse }\end{array}$ \\
\hline $\begin{array}{l}\text { Watercourse bed material }(\mathrm{H}-2) \text { - the } \\
\text { value of the parameter is higher if the } \\
\text { material is natural, diversified, and } \\
\text { unaffected by human activity. Lower } \\
\text { values are assigned to artificial beds or } \\
\text { beds improved by using engineering } \\
\text { materials (such as concrete channels or } \\
\text { groynes) }\end{array}$ & $\begin{array}{l}\text { natural course of the riverbed, very large } \\
\text { diversity of watercourse bed material, } \\
\text { natural occurrence of rough elements }\end{array}$ & $\begin{array}{l}\text { course of the riverbed completely } \\
\text { artificial, concrete }\end{array}$ \\
\hline $\begin{array}{l}\text { Plant life in the channel }(\mathrm{H}-3) \text { - assessed } \\
\text { depending on the degree of channel } \\
\text { improvement and plant potential, in } \\
\text { particular on bars }\end{array}$ & $\begin{array}{l}\text { channel unregulated, presence of various } \\
\text { species of plant life on bars and banks of } \\
\text { the watercourse, natural woody debris }\end{array}$ & $\begin{array}{l}\text { channel is completely regulated } \\
\text { (concrete), absence of vegetation }\end{array}$ \\
\hline $\begin{array}{l}\text { Erosion/ deposition (H-4) - assessed } \\
\text { depending on the present forms } \\
\text { of erosion and deposition, which } \\
\text { is also related to watercourse bed } \\
\text { improvements (or lack thereof) }\end{array}$ & $\begin{array}{l}\text { presence of erosion and deposition } \\
\text { in watercourse channel, presence of } \\
\text { many point bars and mid-channel } \\
\text { bars, existence of natural riffle-pool } \\
\text { sequences, occurring forms of erosion } \\
\text { do not cause undue damage associated } \\
\text { with lateral erosion }\end{array}$ & $\begin{array}{l}\text { watercourse channel completely } \\
\text { regulated (concrete); absence of erosion } \\
\text { or deposition forms }\end{array}$ \\
\hline
\end{tabular}


Nawieśniak-Caesar, M., Hernik, J., Strutyński, M. (2019). Landscape and hydromorphological assessment of a mountain river valley after flood stage. Acta Sci. Pol., Formatio Circumiectus, 18(1), 75-87. DOI: http://dx.doi.org/10.15576/ASP.FC/2019.18.1.75

Table 2. Extreme values of landscape elements as per the LSHM Method

\begin{tabular}{|c|c|c|}
\hline \multirow{2}{*}{ Landscape elements (L) } & \multicolumn{2}{|l|}{ Scale } \\
\hline & $10-9$ & 0 \\
\hline $\begin{array}{l}\text { Land cover and topography (L-1) - } \\
\text { assessed based on visible diversity } \\
\text { (or homogeneity) of topography and land } \\
\text { cover }\end{array}$ & $\begin{array}{l}\text { clearly varied topography and land cover, } \\
\text { presence of hills and valleys, forests, } \\
\text { meadows, cultivated fields; perfectly } \\
\text { harmonised landscape: coexisting landmarks } \\
\text { perfectly match each other, without causing } \\
\text { visual disturbance }\end{array}$ & $\begin{array}{l}\text { topography isn't varied, there is no } \\
\text { diversity in land cover }\end{array}$ \\
\hline $\begin{array}{l}\text { Open landscape (L-2) - values } \\
\text { assigned depending on the occurrence } \\
\text { (or absence) of spatial order and } \\
\text { characteristic features and patterns } \\
\text { related to agriculture and forestry }\end{array}$ & $\begin{array}{l}\text { spatial order, clear boundary between } \\
\text { cultivated fields and forests, high feelings } \\
\text { and associations, distinguishing agricultural } \\
\text { and forestry features and patterns, } \\
\text { preservation of traditional arrangement of } \\
\text { farmland }\end{array}$ & $\begin{array}{l}\text { total absence of spatial order, absence } \\
\text { of boundary between cultivated fields } \\
\text { and forests, as well as distinguishing } \\
\text { agricultural and forestry features } \\
\text { and patterns, absence of traditional } \\
\text { arrangement of farmland }\end{array}$ \\
\hline $\begin{array}{l}\text { Settlement areas (L-3) - assessed } \\
\text { depending on the occurrence (or not) } \\
\text { of region-specific developments and } \\
\text { buildings' condition }\end{array}$ & $\begin{array}{l}\text { spatial order, preserved regional features of } \\
\text { development, high feelings and associations, } \\
\text { visible distinguishing features of houses and } \\
\text { settlements, buildings in good condition }\end{array}$ & $\begin{array}{l}\text { total absence of spatial order, absence } \\
\text { of regional features of development, } \\
\text { buildings preserved in poor condition } \\
\text { with no distinguishing features }\end{array}$ \\
\hline $\begin{array}{l}\text { Historic features/ structures (L-4) - } \\
\text { assessed based on the occurrence of } \\
\text { historic structures, characteristic features, } \\
\text { and patterns of cultural landscape }\end{array}$ & $\begin{array}{l}\text { presence of historic structures (castles, ruins } \\
\text { of castles, walls, etc.), which clearly attract } \\
\text { the observer's attention }\end{array}$ & $\begin{array}{l}\text { absence of historic structures, } \\
\text { distinguishing features or patterns of } \\
\text { the cultural landscape }\end{array}$ \\
\hline
\end{tabular}

Table 3. Extreme values of integrated elements as per the LSHM Method

\begin{tabular}{|c|c|c|}
\hline \multirow{2}{*}{ Integrated elements (I) } & \multicolumn{2}{|r|}{ Scale } \\
\hline & $10-9$ & 0 \\
\hline $\begin{array}{l}\text { Flow characteristics (I-1)-assessed based } \\
\text { on the occurrence (or absence) of diversified } \\
\text { hydromorphological units in watercourse } \\
\text { channel and feelings related to the sound of } \\
\text { flowing water (or lack thereof due to human } \\
\text { activity) }\end{array}$ & $\begin{array}{l}\text { many different hydromorphological } \\
\text { units in watercourse channel, sound } \\
\text { of flowing water is unobstructed by } \\
\text { any anthropogenic activities, } \\
\text { a clear, unique sound landscape }\end{array}$ & $\begin{array}{l}\text { absence of hydromorphological units in } \\
\text { watercourse channel, no sound of flowing } \\
\text { water (completely disturbed by human } \\
\text { activities), no unique sound landscape }\end{array}$ \\
\hline $\begin{array}{l}\text { Anthropogenic elements/ modifications } \\
\text { (I-2) - assessed in watercourse channel and } \\
\text { in river valley based on occurrence } \\
\text { (or absence) of bank and bed modifications } \\
\text { and anthropogenic elements in river valley } \\
\text { that disrupt landscape structure }\end{array}$ & $\begin{array}{l}\text { watercourse channel: completely } \\
\text { natural river channel, no } \\
\text { anthropogenic elements, river } \\
\text { valley: few anthropogenic elements } \\
\text { perfectly integrated into the } \\
\text { landscape, harmonious landscape }\end{array}$ & $\begin{array}{l}\text { watercourse channel: presence of hydraulic } \\
\text { and concrete structures across the channel, } \\
\text { as well as bank and bed revetment made of } \\
\text { artificial materials, river valley: presence of } \\
\text { many artificial, anthropogenic elements that } \\
\text { disturb the spatial order and harmony of the } \\
\text { landscape (e.g. motorways, dumps) }\end{array}$ \\
\hline $\begin{array}{l}\text { Land use and vegetation in areas adjacent } \\
\text { to the watercourse channel (I-3) - assessed } \\
\text { depending on the surface area of the land } \\
\text { adjacent to the channel and its use }\end{array}$ & $\begin{array}{l}\text { area directly adjacent to the } \\
\text { watercourse channel is a wide belt } \\
\text { covered with natural vegetation and } \\
\text { alluvial forests }\end{array}$ & $\begin{array}{l}\text { area directly adjacent to the watercourse } \\
\text { is very narrow and used for technical } \\
\text { infrastructure or development }\end{array}$ \\
\hline $\begin{array}{l}\text { Mobility and connection of the bed to } \\
\text { floodplain and/or adjacent open area (I-4) - } \\
\text { assessed based on the possibility (or not) of } \\
\text { channel shifting in the adjacent area }\end{array}$ & $\begin{array}{l}\text { the channel has an unlimited ability } \\
\text { to shift (meandering, braiding), } \\
\text { very good channel connection to } \\
\text { floodplain and/or adjacent open area }\end{array}$ & $\begin{array}{l}\text { the channel is completely regulated } \\
\text { and unable to shift, absence of channel } \\
\text { connection to floodplain and/or adjacent } \\
\text { open area }\end{array}$ \\
\hline
\end{tabular}




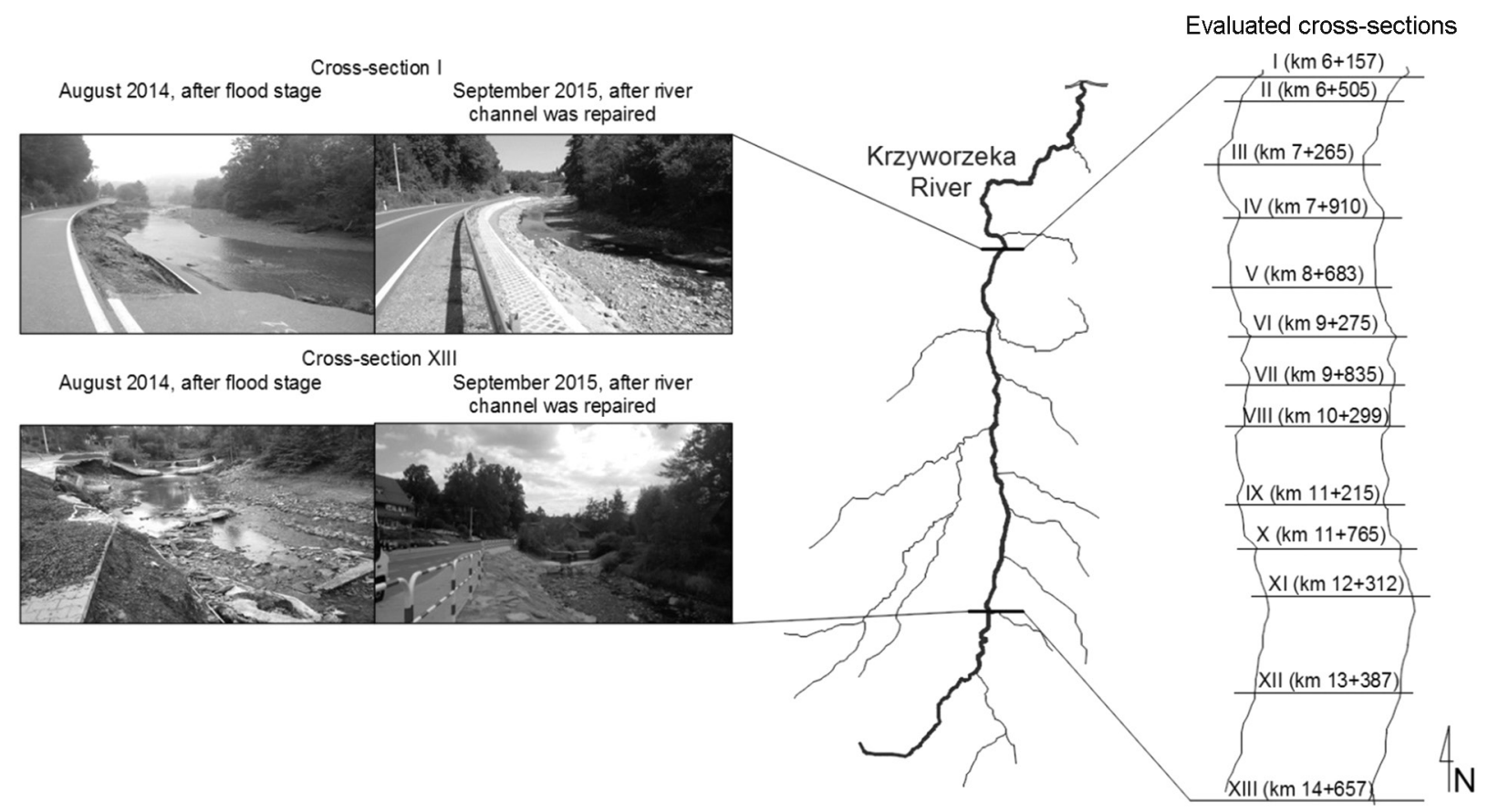

Fig. 2. The examined section of the Krzyworzeka river valley divided into test cross-sections

\section{RESULTS AND DISCUSSION}

In August 2014, the studied area was flooded due to heavy precipitation lasting several days. It was on 6 August that the intensity of rainfall caused flood stage on the Krzyworzeka river within a few hours. The municipalities of Wiśniowa and Raciechowice, whose housing areas are located in a zone adjacent to the river channel, suffered the worst losses. Apart from inundated houses and basements, these included roads and bridges damaged beyond repair.

Immediately after, the hydromorphological and landscape assessment was performed using the LSHM Method. Each parameter in each group of elements was assigned a value. The results are presented (see: Fig. 3) as the value of dispersion, which is the range, or the difference between the highest and the lowest value assigned to parameters in a given group of elements. The intervals thus obtained facilitated the assessment of the area in terms of economic and tourist attractiveness. Additionally, a line of the average value of the parameters was plotted.
After the flood stage, the average value for hydromorphological elements at the examined cross-sections was 6 to 7 (cross-sections III and XI: 5.5). This means that in these sectors, the channel has changed in 5 to $40 \%$. Changes in channel geometry were visible; the longitudinal profile and cross-sections were deformed. Bed of the watercourse had been improved using natural materials: reed, topsoil, and grass. The channel was unregulated. Vegetation was present at the banks and on bars. The channel featured depressions and rapids with scarce deposition landforms (individual mid-channel bars).

The average value for landscape elements in all the investigated cross-sections was 7, which is indicative of diversified topography: hills and valleys. Variability of land cover and spatial order were both visible. Other apparent elements included: boundary between cultivated fields and forests, distinguishing agricultural and forestry features and patterns, and preservation of traditional arrangement of farmland. Regional features of development were preserved: they were noticeable both in the houses and the settlements; most buildings were in good condition. 


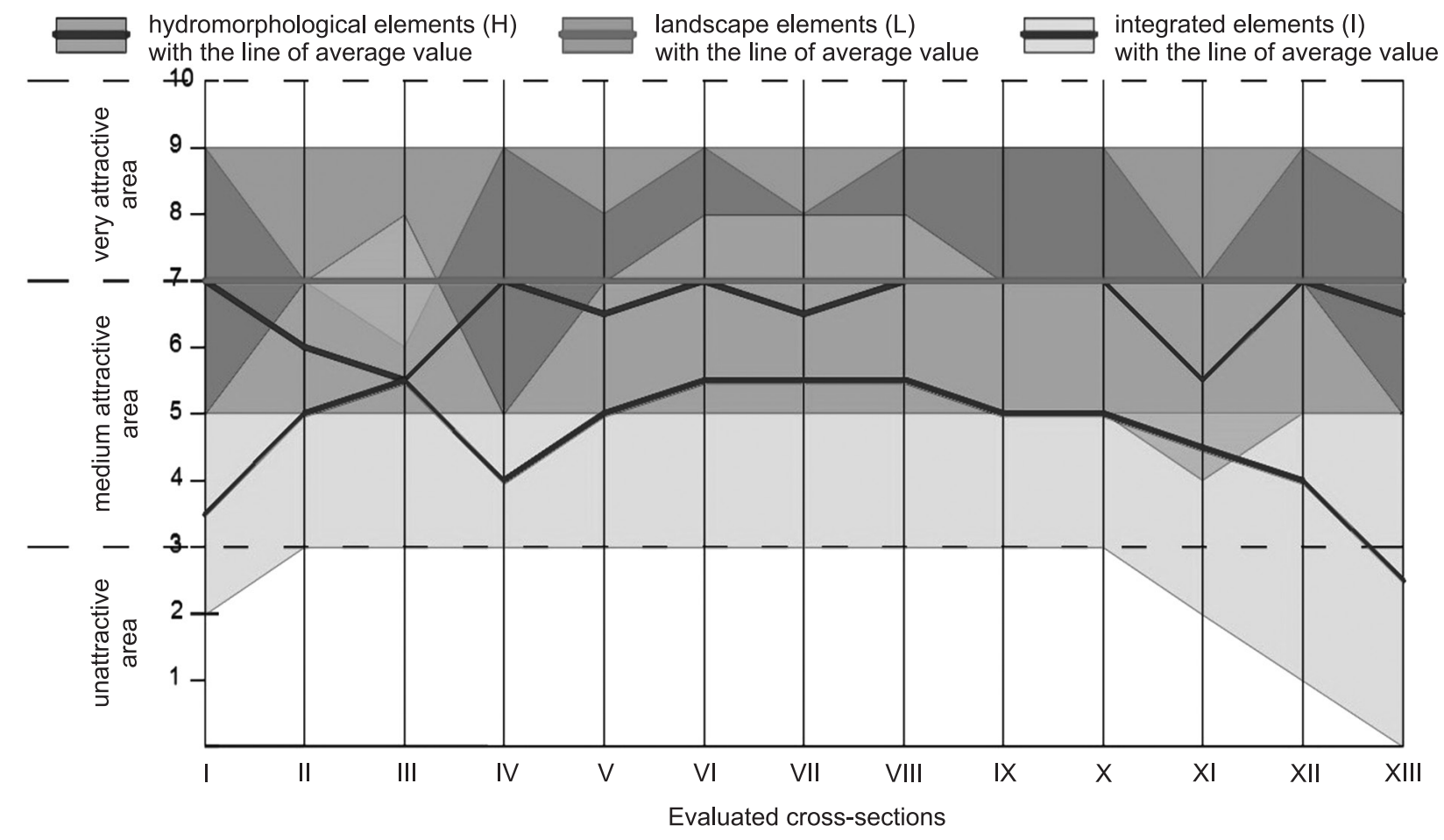

Fig. 3. Diagram with LSHM Method results for the Krzyworzeka river valley obtained in August 2014 after a flood stage

Average values of integrated elements for most examined cross-sections varied from 3.5 to 5 (cross-sections III, VI, VII, and VIII: 5.5). Rarely, in few hydromorphological units in the channel, the sound of flowing water was disturbed by human activity. Both the banks and the bed of the watercourse were modified using natural materials. Anthropogenic elements disturbed the landscape structure in the river valley. The area directly adjacent to the channel was a broad belt of land used for agricultural and/or forest purposes, partially for technical infrastructure. The channel could shift only slightly, but its connection to floodplain and open area was noticeable. This is a large area with high flood risk. The value is 2.5 for cross-section XIII only, which indicates conditions worse than for the other cross-sections.

The second assessment, in September 2015, was conducted in a similar fashion, using the LSHM Method. It was carried out in the same sector following repairs of the regulation of the channel after flood stage (see: Fig. 4).
The average value for hydromorphological elements after restoring regulation in the channel at the examined cross-sections ranged from 3 to 5 . This means that the channel was changed in 40 to $70 \%$. The longitudinal profile, cross-sections, and horizontal position of the watercourse changed substantially. The bed was regulated with natural engineering materials such as stone, gravel, pebbles, broken stone, and sand. The channel featured depressions and rapids, but there were no deposition in the form of bars. Lateral erosion caused uncontrolled, dangerous sliding of the banks (river cliffs), which resulted in transportation of rubble downstream. Watercourse channel was partially regulated; there was vegetation growing on the banks.

The average value of landscape elements for all the examined cross-sections did not change during the second assessment, and it was exactly the same as during the first one, i.e. 7.

Mean values of integrated elements for most examined cross-sections varied from 3 to 5 (cross-sections III, VI, and VII: 5.5) during the second assessment, 


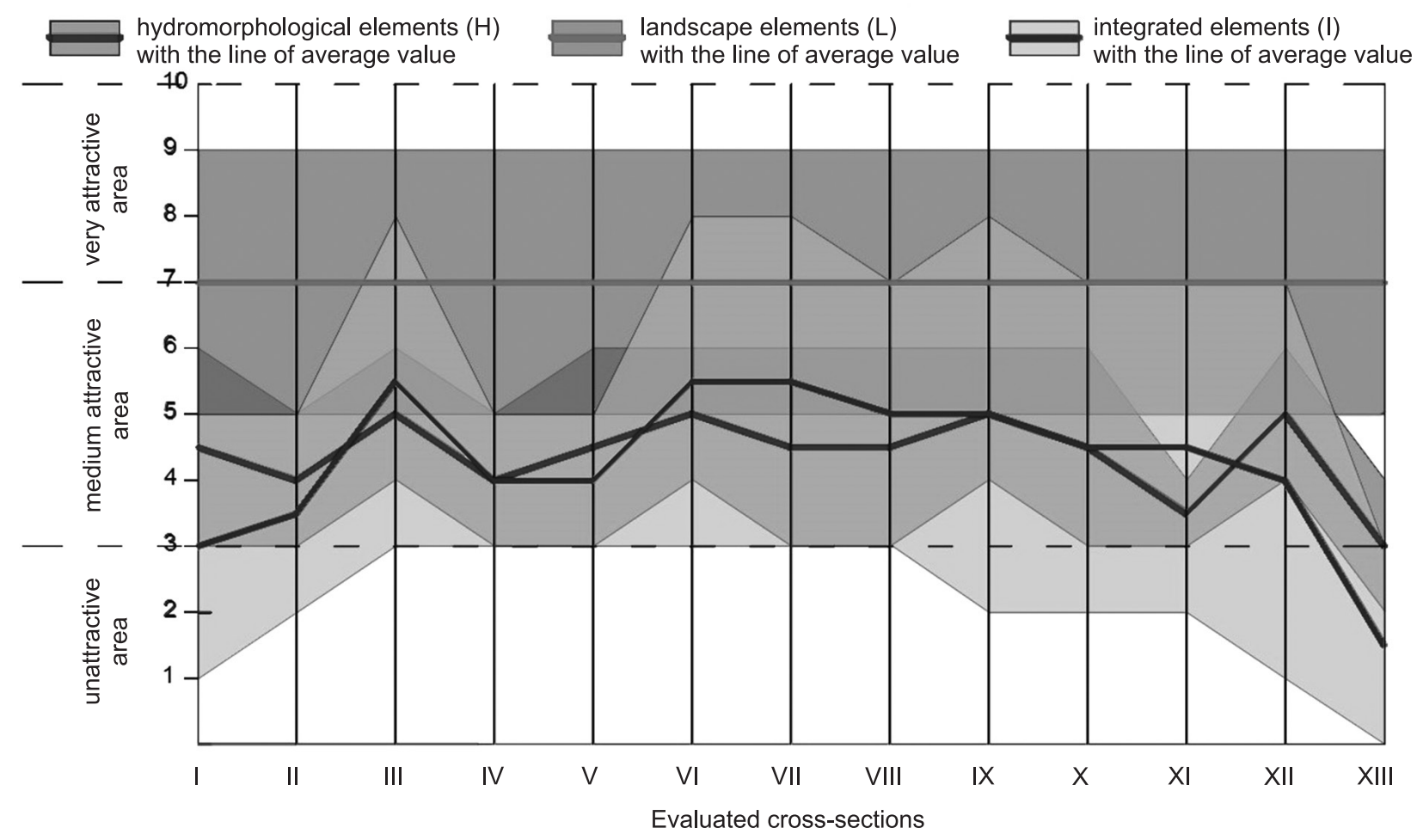

Fig. 4. Diagram with LSHM Method results for the Krzyworzeka river valley obtained in September 2015 after river channel was repaired

which was identical to the first one. Only in the case of cross-section XIII the value of integrated elements was 1.5. Hydrological units/ elements in the channel were rather indistinct. Sound of the flow was disrupted by human activity to a large extent. The modifications to the channel were made using engineering materials (such as concrete). Extremely numerous anthropogenic elements disturbed the landscape structure in the river valley. The area directly adjacent to watercourse was narrow, and it was partially used to house technical infrastructure. The channel could not shift; there was no connection to floodplain and open area. These are vast areas with high flood risk.

Until now, hydromorphological and landscape elements were assessed separately. Hydromorphological assessment methods focused solely on the watercourse channel, while landscape methods focused on the area up to the watercourse boundary. However, river valleys constitute separate natural systems and particular socio-economic systems. Any analysis of transforma- tions to river valley landscape must not be limited to the geomorphological unit (river valley with the channel and terrace system), or the hydromorphological unit (with natural riffle-pool sequences); instead, it should adopt a broader perspective, and focus on entire zones and the key function of valleys: corridors for nature and people (in the meaning of wildlife, as well as social and cultural corridors). When embarking on a study of transformation of river valley landscape, one has to be aware of the influence the river and valley have on their hinterlands (Bernat, 2005) and the quality of life of the people who live in the zone of direct river impact.

The presented results show a significant difference for hydromorphological elements. During the first assessment, the hydromorphological elements were rated high owing to the natural character of the feature, which facilitated unobstructed channel behaviour. The assessment following the repairs resulted in much lower values. The repairs necessitated hydraulic en- 
gineering solutions in order to restore the active channel. These works, in turn, produced a significant transformation of river channel morphology, in particular as regards ecological continuity. The most common material applied in the regulation was quarry stone. Elements used to assess the landscape of the valley do not focus on the channel alone. Hence, the high values after the flood [August 2014] and after the repairs on the channel [September 2015]. The first assessment yielded higher values for integrated elements, in particular for 'mobility and connection of the bed to the floodplain and/or adjacent open area'. This is related to the Krzyworzeka river being located between two roads, with areas of residential development close to the channel, which is characteristic of Carpathian mountain catchments. During the second assessment, integrated elements related more closely to the river channel were rated lower.

The analysis of the changes caused by the flood thus establishes a new approach to the determination of these changes from the point of view of the river valley landscape. The changes are understood not as economic phenomena and factors but as environmental phenomena and factors - both positive and negative modifications to the landscape of river valleys. Currently, the assessment of flood losses has covered only the negative effects of changes in the material (economic/commercial) area; the new method allows for an assessment of changes, which are advantageous and expected in the river ecosystem for the improvement of its hydromorphological condition. This approach results in bringing the watercourse bed closer to the reference values for a given river type, and this contributes to the improvement of the river valley landscape. Therefore, it is possible to define a new concept of hydromorphological and landscape risk, understood as the product of probability of an extreme hydrological phenomenon occurrence with potential negative or positive effects caused by it from a hydromorphological and landscape point of view.

Water is an important component of the natural landscape (Dufour et al., 2015; Vogt et al., 2004; Yamashita, 2002). Mountain rivers and streams in particular have large impact on its shape (Litton, 1977); they undergo constant changes in time and space due to their dynamic nature (Bartnik et al., 2009; Wyżga, 2001). Mountain catchments, such as the Krzy- worzeka river catchment, feature significant gradients, which results in larger runoff, and that in turn causes sudden and uncontrolled high water (Radecki-Pawlik, 2011). Morphological transformations of river channels are affected by natural and anthropogenic factors (Naiman et al., 2005; Ward et al., 2002; Whited et al., 2007). The LSHM Method included anthropogenic factors under integrated elements: anthropogenic elements/modifications (I-2). They influence the value of the assessed hydromorphological elements $(\mathrm{H})$ as well (Nawieśniak et al., 2016).

The developed LSHM Method makes it possible to show the areas that require improvement as regards hydromorphological and landscape components so as to make them attractive, and the areas that do not need such an improvement. This will allow finding of the social, landscape and hydromorphological benefits that may be derived from this area to the benefit of tourism, recreation and economic use of river valleys (e.g. fishing, power industry). Additionally, the assessment of valorisation according to this method allows for the pinpointing of areas, which are dependent on the river and the landscape that is connected with the hydromorphological changes in the watercourse bed. The specified zone of river-dependent areas will be characterised by a domination of hydromorphological components over landscape components. It will be possible to show thus determined zones graphically through mapping (Nawieśniak et al., 2016).

Frequently, landscape changes are seen as a threat, a negative evolution resulting in the loss of biodiversity, integrity and identity of a region. New elements and structures are added to the landscape, which are much the same in all respects. However, we cannot forget that the landscape changes all the time, through dynamic interaction of both natural and cultural forces. Culture-related landscapes are the result of land reorganisation in order to ensure better adaptation of its land use and spatial structure to changing social needs (Antrop, 2005).

\section{CONCLUSIONS}

Mountain river valleys undergo constant changes in time and space. Application of the LSHM Method to assess changes in the Krzyworzeka river valley after flood stage facilitated identification of areas in need of 
improvements due to hydromorphological and landscape elements as well as areas not requiring any enhancements.

This will facilitate discerning social, landscape, and hydromorphological benefits of the area for tourism, leisure, and economic use of river valleys.

Hydromorphological and landscape assessment with the LSHM Method facilitates the identification of transformations of both the river channel and valley in terms of the function of wildlife corridor together with areas interrelated with the river, as well as the assessment of integrated river valley landscape as an element determining attractiveness of the area or a space with a significant development potential. Balanced approach to hydromorphology and landscape changes after flood stage facilitates assessing complementarity of repairs and maintenance and their impact on the economic growth of the region.

Using the LSHM Method enables assessment of changes in the river ecosystems. Having information about the changes in the river ecosystems facilitates improvements, which strengthen its hydromorphological condition. Applying this method thus results in the bed of the watercourse being brought closer to the reference values of a given river type. This in turn contributes to an improved river valley landscape.

So far, the method was tested only on mountain river valleys in Poland. The nature of these areas and shape of river valleys is substantially different than for the lowlands. Authors hope that it would be possible to apply the LSHM Method to lowlands as well, following a modification in the manner of assessing some of the parameters that are currently included.

\section{ACKNOWLEDGMENTS}

This Research was financed by the Ministry of Science and Higher Education of the Republic of Poland, project No. DS 3371/KGPiAK/2018.

\section{REFERENCES}

Allaire, M.C.; Vogel, R.M.; Kroll, C.N. (2015). The hydromorphology of an urbanizing watershed using multivariate elasticity. Advances in Water Resources, 86, 147-154.

Antrop, M. 2005. Why landscapes of the past are important for the future. Landscape Urban Plan., 70, 21-34.
Bartnik, W.; Bonenberg, J.; Florek, J. (2009). The influence of the loos of natural water storage capacity of a river basin on the morphological characteristic of the river and its basin. Infrastructure and ecology of rural areas. Monograph series, 2/2009.

Belletti, B.; Rinaldi, M.; Buijse, A.D.; Gurnell, A.M.; Mosselman, E. (2015). A review of assessment methods for river hydromorphology. Environm. Earth Sci., 73, 2079-2100.

Bernat, S. (2005). Ewolucja krajobrazu kulturowego doliny środkowego Bugu. Annales UMCS Sectio B, 60, 197216 (in Polish).

Casado, M.R.; Gonzalez, R.B.; Kriechbaumer, T.; Veal A. (2015). Automated Identyfication of River Hydromorphological Features Usin UAV High Resolution Aerial Imagery. Sensors, 15, 27969-27989.

Council of Europe. (2000). European Landscape Convention. CETS No. 176. Council of Europe, Strasbourg.

Directive 2000/60/EC of the European Parliament and of the Council of 23 October 2000 establishing a framework for community action in the field of water policy.

Directive 2007/60/EC of the European Parliament and of the Council of 23 October 2007 on the assessment and management of flood risks.

Dufour, S.; Rinaldi, M.; Piégay, H.; Michalon, A. (2015). How do river dynamics and human influences affect the landscape pattern of fluvial corridors? Lessons from the Magra River, Central-Northern Italy. Landscape Urban Plan., 134, 107-118.

Gulinck, H.; Wagendorp, T. (2002). References for fragmentation analysis of the rural matrix in cultural landscapes. Landscape Urban Plan., 58, 137-146.

Hernik, J. (2008). Potrzeba uwzględnienia walorów krajobrazu kulturowego w zarządzaniu gminą wiejską. Dissertation of Cultural Landscape Commission, 10, 61-68 (in Polish).

Hernik, J.; Gawroński, K.; Dixon-Gough, R. (2013). Social and conflicts between cultural landscapes and rural communities in the English and Polish systems. Lan Use Policy, 30, 800-813.

Ilnicki, P.; Lewandowski, P. (1997). Ekomorfologiczna waloryzacja dróg wodnych Wielkopolski. Wyd. Nauk. Bogucki, Poznań (in Polish).

Ioana-Toroimac, G.; Zaharia, L.; Minea, G. (2015). Using Pressure and Alternation Indicators to Assess River Morphological Quality: Case Study of the Prahova River (Romania). Water, 7, 2971-2989.

Kühne, O.; Gawroński, K.; Hernik, J., (2015). Transformation and Landschaft: die Folgen sozialer Wandlungsprozesse auf Landschaft. Springer VS (in Germany). 
Nawieśniak-Caesar, M., Hernik, J., Strutyński, M. (2019). Landscape and hydromorphological assessment of a mountain river valley after flood stage. Acta Sci. Pol., Formatio Circumiectus, 18(1), 75-87. DOI: http://dx.doi.org/10.15576/ASP.FC/2019.18.1.75

Lewandowski, P. (2012). Polish Investigations on River Hydromorphology. Pol. J. Environ. Stud., 21, 957-965.

Litton, Jr.R.B. (1977). River landscape quality and its assessment. In Proceedings of the Symposium on River Recreation Management and Research. Gen. Tech. Rep. NC-28, Northcentral For. Exp. Stn. US Department of Agriculture, St. Paul, MN, 46-54.

Merz, B.; Elmer, F.; Thieken, A.H. (2009). Significance of "high probability/low damage" versus "low probability/high damage" flood events. Nat. Hazards Earth Syst. Sci., 9, 1033-1046.

Naiman, R.J.; Décamps, H.; McCLain, M. (2005). Riparia, ecology, conservation and management of streamside communities. San Diego. CA: Academic Press, Elsevier.

Nawieśniak, M. (2018). Hydromorphological and landscape assessment of the Białka river valley. Acta Sci. Pol., Formatio Circumiectus, 17(2), 3-11.

Nawieśniak, M.; Strutyński, M.; Hernik, J. (2016). Hyromorphological and landscape valorisation of river valleys based on the Carpathian Poprad river valley study. Carpath. J. Earth Env., 11, 207-219.

Oglęcki, P.; Pawłat, H. (2000). The index method of small lowland river environmental evaluation. Ann. Warsaw Agricult. Univ., Land Reclam., 30, 37-43.

Radecki-Pawlik, A. (1999). Bench index method as a way of bankfull discharge determination on mountain creeks in the polish Carpathian. EJPAU, 2, 1-8.

Radecki-Pawlik, A. (2002). Bankfull discharge in mountain streams: theory and practice. Earth Surf. Process. Landforms, 27, 115-123.

Radecki-Pawlik, A. (2011). Hydromorfologia rzek i potoków górskich. Działy wybrane. Agricultural University in Kraków, Kraków (in Polish).

Raszeja, E.; Skóra, A. (2018). Ochrona dolin rzecznych Wielkopolski w aspekcie percepcji krajobrazu na przykładzie doliny Samicy Kierskiej. Acta Sci. Pol., Formatio Circumiectus, 17(1), 59-73 (in Polish).

Raven, P.J.; Holmes, N.T.H.; Dawson, F.H.; Fox, P.J.A.; Everard, M.; Fozzard, I.; Rouen, K. J. (1998a). River Habitat Quality: the Physical Character of Rivers and Streams in the UK and the Isle of Man. Environment Agency, Bristol.

Raven, P.J.; Holmes, N.T.H.; Dawson, F.H.; Everard, M. (1998b). Quality assessment using River Habitat Survey data. Aquatic Conser6: Mar. Freshw. Ecosyst., 8, 405-424.

Rinaldi, M.; Belleti, B.; van de Bund, W.; Bertoldi, W.; Gurnell, A.; Buijse, T.; Mosselman, E. (2013). Review on Eco-Hydromorphological Methods. Deliverable 1.1, REFORM (Restoring Rivers for Effective Catchment
Management). European Commission: Belgium, Germany.

Sankowski, E.; Harris, B.J.; Hernik, J. (2016). Some problems and possibilities for sustainable development. Krakow: Publishing House of the University of Agriculture.

Solecka, I.; Raszka, B.; Krajewski, P. (2018). Landscape analysis for sustainable land use policy: A case study in the municipality of Popielów, Poland. Land Use Policy 75(2018), 116-126.

Spänhoff, B.; Dimmer, R.; Friese, H.; Harnapp, S.; Herbst, F.; Jenemann, K.; Mickel, A.; Rohde, S.; Schönherr, M.; Ziegler, K.; Kuhn, K.; Müller, U. (2012). Ecological Status of Rivers and Streams in Saxony (Germany) According to the Water Framework Directive and Prospects of Improvement. Water, 4, 887-904.

Stoeglehner, G.; Schmid, J. (2007). Development of cultural landscapes - Austrian situation and future perspective in the light of the ELC. Chapter in J. Hernik, J.M. Pijanowski, J.M. (Eds.). CULTURAL LANDSCAPE Assessment, Protection, Shaping. Agricultural University in Kraków, Kraków, 59-67.

Spiegler, A.; Dower, M. (2006). ECOVAST Landscape Identification - a guide to good practice. [online], [cited 21.10.2018]. Available from Internet: www.ecovast.org

Szoszkiewicz, K.; Jusik, S.; Adynkiewicz-Piragas, M.; Gebler, D.; Achtenberg, K.; Radecki-Pawlik, A.; Okruszko, T.; Giełczewski, M.; Pietruczuk, K.; Przesmycki, M.; Nawrocki, P. (2017). Ocena wód płynących w oparciu o hydromorfologiczny indeks rzeczny (HIR). Podręcznik obserwacji hydromorfologicznych elementów oceny stanu ekologicznego wód płynących zgodnych z normą PN_EN 14614:2008. Inspekcja Ochrony Środowiska, Warszawa (in Polish).

Vogt, J.; Puumalainen, J.; Kennedy, P.; Folving, S. (2004). Integrating information on river networks catchments and major forest types: toward the characterisation and analysis of European landscapes. Landscape Urban Plan., 67, 27-41.

Ward, J.V.; Tockner, K.; Arscott, B.D.; Claret, C. (2002). Riverine landscape diversity. Freshwater Biology, 47, 517-539.

Whited, D.C.; Lorang, M.S.; Harner, M.J.; Hauer, F.R.; Kimball, J.S.; Stanford, J.A. (2007). Climate, hydrologic disturbance, and succession: Drivers of floodplain pattern. Ecology, 88, 940-953.

Wiens, J.A. (2002). Riverine landscapes: taking landscape ecology into the water. Freshwater Biology, 47, 501-515.

Wyżga, B. (2001). A geomorphologist's criticism of the engineering approach to channelization of gravel-bed riv- 
ers: case study of the Raba River, Polish Carpathians. Environmental Management, 28, 341-358.

Wyżga, B.; Amirowicz, A.; Radecki-Pawlik, A.; Zawiejska, J. (2009). Hydromorphological conditions, potential fish habitats, and the fish community in a mountain river subjected to variable human impacts, the Czarny Dunajec. Polish Carpathians. River Research and Applications, 25, 517-536.

Wyżga, B.; Zawiejska, J.; Radecki-Pawlik, A.; Amirowicz, A. (2010). A method for the assessment of hydromorphological river quality and its application to the Czarny Dunajec, Poilsh Carpathians. In Cultural Land- scapes of River Valleys. Radecki-Pawlik, A.; Hernik, J. Eds. Agricultural University in Kraków, Kraków, $145-164$

Wyżga, B.; Zawiejska, J.; Radecki-Pawlik, A.; Hajdukiewicz, H. (2012). Environmental change, hydromorphological reference conditions and the restoration of Polish Carpathians rivers. Earth Surface Processes and Landforms, 37, 1213-1226.

Yamashita, S. (2002). Perception and evaluation of water in landscape: use of Photo-Projective Method to compare child and adult residents' perceptions of a Japanese river environment. Landscape Urban Plan., 62, 3-17.

\section{KRAJOBRAZOWO-HYDROMORFOLOGICZNA OCENA GÓRSKIEJ DOLINY RZECZNEJ PO POWODZI}

\section{ABSTRAKT}

\section{Cel pracy}

Zintegrowana ocena zmian krajobrazowo-hydromorfologicznych w górskiej dolinie rzecznej po powodzi.

\section{Materiał i metody}

Ocenę przeprowadzono metodą LandScape \& HydroMorfological Assessment of River Valleys (metoda LSHM). Metoda ta służy do oceny i identyfikacji cennych obszarów w dolinach rzecznych i określania ich potencjału rozwojowego. Metoda LSHM rozróżnia trzy główne grupy czynników: hydromorfologiczne $(\mathrm{H})$, krajobrazowe (L) i zintegrowane (I). Wszystkie czynniki są oceniane przy użyciu 10-punktowej skali.

\section{Wyniki i wnioski}

Ocena krajobrazowo-hydromorfologiczna wykonana za pomocą metody LSHM, ułatwia identyfikację przekształceń zarówno w korycie rzeki, jak i w całej dolinie oraz ocenę krajobrazu doliny rzecznej. Zintegrowane podejście można zastosować do napraw po powodziowych w dolinie rzecznej.

Słowa kluczowe: waloryzacja hydromorfologiczna i krajobrazowa, metoda LSHM, doliny rzek, powódź 